\title{
Spectrum of Surgically Treated Thyroid Carcinoma in Latvia
}

\author{
Ilze Strumfa*, Didzis Gailis*, Ervins Vasko*, Andrejs Vanags**, Arturs Ozolins**, Ivanda Franckevica*, Tatjana \\ Bogdanova*, Janis Gardovskis** \\ *Department of Pathology, Riga Stradins University, Latvia \\ ${ }^{* *}$ Department of Surgery, Riga Stradins University, Latvia
}

\begin{abstract}
SUMMARY
Introduction. Health care statistics provides a solid evidence of increasing thyroid cancer prevalence in Latvia. However, in order to characterise the problem of thyroid cancer more completely, histological type and stage of carcinomas as well as demographic characteristics of the affected patients would be as important as the total burden of new cases.

Aim of the study was to provide detailed characteristics of the spectrum of surgically treated primary thyroid carcinoma.

Materials and methods. The study was designed as retrospective research. Archives of a single university hospital were searched for consecutive, surgically treated or histologically proved cases of primary thyroid carcinoma (2008 - 2012). Each case was characterised by histological type, local tumour spread, largest diameter of the carcinoma, patient's age and sex as well as extent of surgical treatment. Descriptive statistics was carried out by CIA software.

Results. Archive search yielded 323 primary thyroid carcinoma cases, including 255 cases $(78.9 \% ; 95 \%$ confidence interval $(\mathrm{Cl})=$ $74.2-83.0)$ of papillary carcinoma, 54 cases $(16.7 \% ; 95 \% \mathrm{Cl}=13.1-21.2 \%)$ of follicular carcinoma and $7 \mathrm{cases}(2.2 \% ; 95 \% \mathrm{Cl}=$ $1.1-4.4 \%$ ) of medullary and anaplastic carcinoma. Although the youngest cases (aged 18 and 20 years) were diagnosed with papillary and follicular carcinoma, respectively, the mean age did not show statistically significant differences between the groups. Strong female predominance was observed regardless of cancer type. Regarding local tumour spread, pT1a was significantly more frequent in papillary carcinoma: $50.2 \%(95 \% \mathrm{Cl}=44.1-56.3)$ in contrast to $18.5 \%(95 \% \mathrm{Cl}=10.4-28.9)$ in case of follicular carcinoma. Total thyroidectomy was the most frequent type of operation that was applied for $28.6-71.4 \%$ cases in relation to histological type.

Conclusions. This is the first research work in Latvia that comprehends the overall review of the morphological spectrum of thyroid carcinoma in the surgical material. Papillary and follicular carcinomas are the most frequently identified types in accordance with the global data. Much less common morphological forms of thyroid tumours were also diagnosed - medullary carcinoma and anaplastic thyroid carcinoma. The large mean diameter of follicular carcinoma in the surgery material and the fact that more than half of follicular carcinomas are revealed as PT2-T3 tumours highlights the necessity for up-to-dated diagnostics and elaboration of reliable novel molecular tests.
\end{abstract}

Key words: Thyroid cancer, papillary carcinoma, follicular carcinoma, anaplastic carcinoma.

\section{INTRODUCTION}

Growing incidence of thyroid cancer has been reported worldwide, including Europe (Ceresini et al., 2012). The increasing incidence has been attributed to improved diagnostics. However, several observations suggest true increase in incidence. In USA studies, increase in the incidence of thyroid cancer was observed regardless of tumour size (Chen et al., 2009). In addition, the thyroid cancer mortality has remain unchanged or even increased (Davies and Welch, 2006; Ceresini et al., 2012; Pellegriti et al., 2013).

Latvia, as many Western populations, experiences a rise of thyroid cancer incidence. The number of new cases per year (1990-2012) is shown in Figure 1. However, in order to characterise the problem of thyroid cancer more completely, histological type, stage and demographic characteristics would be as important as the total burden of new cases. The thyroid cancer incidence is known to be highly variable (with up to tenfold differences) by geographic area and ethnicity (Pellegriti et al., 2013). Variations in the more detailed characteristics can be expected as well. Thus, to promote further research of thyroid cancer in Latvia, comprehensive characteristics of thyroid cancer by evidence-based data are necessary.

\section{AIM OF THE STUDY}

The aim of the present research was to characterise the spectrum of thyroid cancer in Latvia by histologic type, local tumour spread, cancer size, patients' demographic characteristics and the applied surgical approach in order to create the basis for further clinical and molecular research of thyroid cancer in Latvia.

\section{MATERIALS AND METHODS}

Archives of a single university hospital were searched for consecutive, surgically treated or histologically proved cases of primary thyroid cancer, 2008 - 2012 . The identified cases were reviewed by three pathologists 
to confirm the diagnosis by consensus and to detect the histological type. The thyroid cancers were diagnosed in accordance with World Health Organisation histological classification of thyroid tumours (DeLellis et al., 2004). The $\mathrm{T}$ characteristics, age and sex of the patient as well as the extent of thyroid surgery were retrieved from medical documentation. The local spread of the tumour (pT) was assessed in accordance with American Joint Committee on Cancer (AJCC) Cancer Staging Manual, 7th ed. (Edge et al., 2010) as shown in Table 1. In case if patient had had repeated thyroid surgery within 2 months, the total extent was recorded. Descriptive statistics was performed by Confidence Interval Analysis (CIA) software as described by Altman et al., 2000.

Table 1. Local tumour spread (pT) of thyroid cancer

\begin{tabular}{|l|l|}
\hline pTx & The primary tumour cannot be assessed \\
\hline pT0 & No evidence of primary tumour \\
\hline pT1 & $\begin{array}{l}\text { Tumour not exceeding } 2 \mathrm{~cm} \text { in greatest } \\
\text { dimension, limited to the thyroid }\end{array}$ \\
\hline pTla & $\begin{array}{l}\text { Tumour not exceeding 1 cm in greatest } \\
\text { dimension, limited to the thyroid }\end{array}$ \\
\hline pT1b & $\begin{array}{l}\text { Tumour larger than l cm but not exceeding 2 } \\
\text { cm in greatest dimension, limited to the thyroid }\end{array}$ \\
\hline pT2 & $\begin{array}{l}\text { Tumour larger than 2 cm but not exceeding 4 } \\
\text { cm in greatest dimension, limited to the thyroid }\end{array}$ \\
\hline pT3 & $\begin{array}{l}\text { Tumour exceeding 4 cm in greatest dimension, } \\
\text { limited to the thyroid OR any tumour with } \\
\text { minimal extrathyroid extension, including } \\
\text { extension to perithyroid soft tissues }\end{array}$ \\
\hline pT4 & $\begin{array}{l}\text { Tumour of any size extending beyond thyroid } \\
\text { capsule to invade subcutaneous soft tissues or } \\
\text { other organs OR anaplastic thyroid carcinoma }\end{array}$ \\
\hline
\end{tabular}

\section{RESULTS}

Over the researched period, 323 primary thyroid carcinoma cases were identified. The spectrum of these tumours is depicted in Table 2 and Figure 2. Papillary carcinoma was the most frequent type (255 cases or $78.9 \%$ ), followed by follicular carcinoma at reasonably high proportion (54 cases or $16.7 \%$ ). Medullary and anaplastic carcinoma constituted only $2.2 \%$ of the total group.

Table 2. Spectrum of primary thyroid carcinoma by histologic type

\begin{tabular}{|l|c|c|c|}
\hline \multicolumn{1}{|c|}{ Carcinoma type } & \multirow{2}{*}{$\begin{array}{c}\text { Absolute } \\
\text { number }\end{array}$} & \multicolumn{2}{|c|}{ Proportion } \\
\cline { 3 - 4 } & & $\%$ & $\begin{array}{c}95 \% \\
\text { confidence } \\
\text { interval }\end{array}$ \\
\hline Papillary carcinoma & 255 & 78.9 & $74.2-83.0$ \\
\hline Follicular carcinoma & 54 & 16.7 & $13.1-21.2$ \\
\hline Medullary carcinoma & 7 & 2.2 & $1.1-4.4$ \\
\hline Anaplastic carcinoma & 7 & 2.2 & $1.1-4.4$ \\
\hline Total & 323 & 100.0 & Not applicable \\
\hline
\end{tabular}

The age and sex characteristics of primary thyroid carcinoma are revealed in Tables 3 and 4 . The mean age was lower in the group of papillary carcinoma: 55.6 years $(95 \%$ CI $=53.9-57.3$ years $)$ and follicular carcinoma: 54.4 years $(95 \%$ CI $=49.9-58.9$ years $)$. Medullary and anaplastic carcinoma occurred in groups with higher mean age: 61.3 years $(95 \% \mathrm{CI}=52.0-70.6$ years) and 66.4 years $(95 \%$ CI $=53.8-79.0$ years $)$, correspondingly. The differences were statistically insignificant. Only papillary and follicular carcinomas were diagnosed in young persons, even $18-20$ years old.

Table 3. The age characteristics of patients diagnosed with primary thyroid carcinoma

\begin{tabular}{|l|c|c|c|c|}
\hline \multirow{2}{*}{ Cancer type } & \multicolumn{2}{|c|}{ Mean age, years } & \multicolumn{2}{c|}{ Age range, years } \\
\cline { 2 - 5 } & Value & $95 \%$ CI & Minimal & Maximal \\
\hline $\begin{array}{l}\text { Papillary } \\
\text { carcinoma }\end{array}$ & 55.6 & $53.9-57.3$ & 18 & 88 \\
\hline $\begin{array}{l}\text { Follicular } \\
\text { carcinoma }\end{array}$ & 54.4 & $49.9-58.9$ & 20 & 85 \\
\hline $\begin{array}{l}\text { Medullary } \\
\text { carcinoma }\end{array}$ & 61.3 & $52.0-70.6$ & 46 & 74 \\
\hline $\begin{array}{l}\text { Anaplastic } \\
\text { carcinoma }\end{array}$ & 66.4 & $53.8-79.0$ & 46 & 85 \\
\hline
\end{tabular}

Abbreviation in the Table: CI, confidence interval

Table 4. The sex characteristics of patients affected by primary thyroid carcinoma

\begin{tabular}{|c|c|c|c|}
\hline \multirow{2}{*}{$\begin{array}{l}\text { Cancer } \\
\text { type }\end{array}$} & \multicolumn{3}{|c|}{ Females } \\
\hline & $\begin{array}{c}\text { Absolute } \\
\text { number }\end{array}$ & Percentage & $95 \% \mathrm{CI}$ \\
\hline $\begin{array}{l}\text { Papillary } \\
\text { carcinoma }\end{array}$ & $222 / 255$ & 87.1 & $82.4-90.6$ \\
\hline $\begin{array}{l}\text { Follicular } \\
\text { carcinoma }\end{array}$ & $48 / 54$ & 88.9 & $77.8-94.8$ \\
\hline $\begin{array}{l}\text { Medullary } \\
\text { carcinoma }\end{array}$ & $5 / 7$ & 71.4 & $35.9-91.8$ \\
\hline $\begin{array}{l}\text { Anaplastic } \\
\text { carcinoma }\end{array}$ & $7 / 7$ & 100 & $64.6-100.0$ \\
\hline
\end{tabular}

Abbreviation in the Table: CI, confidence interval

The local spread (pT characteristics) of thyroid cancer is shown in Table 5. Papillary carcinoma was mostly revealed as pTla while follicular carcinoma is characterised by more marked local spread. This difference is statistically significant. The mean largest diameter of all radically removed thyroid carcinomas was $1.7 \mathrm{~cm}(95 \% \mathrm{CI}=1.5-1.9)$, but the mean largest diameter by tumour types was following: papillary carcinoma $-1.4 \mathrm{~cm}(95 \% \mathrm{CI}=1.2-1.6)$, follicular carcinoma $-2.9 \mathrm{~cm}(95 \% \mathrm{CI}=2.2-3.6)$ and medullary carcinoma $-1.5 \mathrm{~cm}(95 \% \mathrm{CI}=0.4-2.6)$. 
Table 5. pT characteristics of primary thyroid carcinoma

\begin{tabular}{|c|c|c|c|c|c|c|c|c|c|}
\hline $\begin{array}{l}\text { Carcinoma } \\
\text { type }\end{array}$ & Parameter & Tla & $\mathrm{Tlb}$ & T1, NOS & $\mathrm{T} 2$ & T3 & $\mathrm{Tx}$ & $\mathrm{T}>1$ & Total \\
\hline \multirow{3}{*}{$\begin{array}{l}\text { Papillary } \\
\text { carcinoma }\end{array}$} & Number & 128 & 45 & 11 & 30 & 39 & 2 & 69 & \multirow[t]{3}{*}{255} \\
\hline & $\begin{array}{c}\text { Fraction, } \\
\% \\
\end{array}$ & 50.2 & 17.7 & 4.3 & 11.8 & 15.3 & 0.8 & 27.1 & \\
\hline & $95 \% \mathrm{CI}$ & $44.1-56.3$ & $\begin{array}{l}13.5- \\
22.8\end{array}$ & $2.4-7.6$ & $8.4-16.3$ & $\begin{array}{c}11.4- \\
20.1\end{array}$ & $0.2-2.8$ & $22.0-32.8$ & \\
\hline \multirow{3}{*}{$\begin{array}{l}\text { Follicular } \\
\text { carcinoma }\end{array}$} & Number & 10 & 11 & 2 & 14 & 15 & 2 & 29 & \multirow[t]{3}{*}{54} \\
\hline & $\begin{array}{c}\text { Fraction, } \\
\%\end{array}$ & 18.5 & 20.4 & 3.7 & 25.9 & 27.8 & 3.7 & 53.7 & \\
\hline & $95 \% \mathrm{CI}$ & $10.4-28.9$ & $\begin{array}{c}11.8- \\
32.9 \\
\end{array}$ & $1.0-12.5$ & $\begin{array}{c}16.1- \\
38.9 \\
\end{array}$ & $\begin{array}{c}17.6- \\
40.9 \\
\end{array}$ & $1.0-12.5$ & $40.6-66.3$ & \\
\hline \multirow{3}{*}{$\begin{array}{l}\text { Medullary } \\
\text { carcinoma }\end{array}$} & Number & 3 & 1 & 0 & 2 & 1 & 0 & 3 & \multirow[t]{3}{*}{7} \\
\hline & $\begin{array}{c}\text { Fraction, } \\
\% \\
\end{array}$ & 42.9 & 14.3 & 0.0 & 28.6 & 14.3 & 0.0 & 42.9 & \\
\hline & $95 \% \mathrm{CI}$ & $15.8-75.0$ & $2.6-51.3$ & $0.0-35.4$ & $8.2-64.1$ & $2.6-51.3$ & $0.0-35.4$ & $15.8-75.0$ & \\
\hline
\end{tabular}

Abbreviation in the Table: NOS, not otherwise specified; CI, confidence interval

The surgical approach to thyroid cancer is described in Table 6. Total thyroidectomy was the most common surgical procedure in all thyroid cancer subtypes reaching statistically significant difference regarding the rates of other operations for papillary carcinoma: total thyroidectomy was carried out in $60.0 \%$ of cases $(95 \%$ CI $=53.9-65.8)$ in contrast to subtotal thyroidectomy in $19.2 \%$ patients $(95 \% \mathrm{CI}=14.9-24.5)$ and hemithyroidectomy in $17.7 \%$ of cases $(95 \% \mathrm{CI}=13.5-22.8)$. There is similar trend in comparison between the rates of total thyroidectomy versus subtotal thyroidectomy in follicular carcinoma: $50.0 \%(95 \% \mathrm{CI}=37.1-62.9)$ and $18.5 \%(95 \% \mathrm{CI}=10.4-30.8)$, respectively. In anaplastic carcinoma, three potentially curative operations and one palliative tumour resection was carried out. In three patients, only diagnostic core biopsy was possible.

Table 6. Surgical treatment of primary thyroid carcinoma

\begin{tabular}{|c|c|c|c|c|c|c|}
\hline Cancer type & Parameter & $\begin{array}{l}\text { Total thyroid- } \\
\text { ectomy }\end{array}$ & $\begin{array}{c}\text { Subtotal } \\
\text { thyroidectomy }\end{array}$ & $\begin{array}{l}\text { Hemithyroid- } \\
\text { ectomy }\end{array}$ & Other & Total \\
\hline \multirow{3}{*}{$\begin{array}{l}\text { Papillary } \\
\text { carcinoma }\end{array}$} & Number & 153 & 49 & 45 & 8 & \multirow[t]{3}{*}{255} \\
\hline & Fraction, \% & 60.0 & 19.2 & 17.7 & 3.1 & \\
\hline & $95 \% \mathrm{CI}$ & $53.9-65.8$ & $14.9-24.5$ & $13.5-22.8$ & $1.6-6.1$ & \\
\hline \multirow{3}{*}{$\begin{array}{l}\text { Follicular } \\
\text { carcinoma }\end{array}$} & Number & 27 & 10 & 14 & 3 & \multirow[t]{3}{*}{54} \\
\hline & Fraction, \% & 50.0 & 18.5 & 25.9 & 5.6 & \\
\hline & $95 \% \mathrm{CI}$ & $37.1-62.9$ & $10.4-30.8$ & $16.1-38.9$ & $1.9-15.1$ & \\
\hline \multirow{3}{*}{$\begin{array}{l}\text { Medullary } \\
\text { carcinoma }\end{array}$} & Number & 5 & 1 & 1 & 0 & \multirow[t]{3}{*}{7} \\
\hline & Fraction, \% & 71.4 & 14.3 & 14.3 & 0.0 & \\
\hline & $95 \% \mathrm{CI}$ & $35.9-91.8$ & $2.6-51.3$ & $2.6-51.3$ & $0.0-35.4$ & \\
\hline \multirow{3}{*}{$\begin{array}{l}\text { Anaplastic } \\
\text { carcinoma }\end{array}$} & Number & 2 & 0 & 1 & 1 & \multirow[t]{3}{*}{7} \\
\hline & Fraction, \% & 28.6 & 0.0 & 14.3 & 14.3 & \\
\hline & $95 \% \mathrm{CI}$ & $8.2-64.1$ & $0.0-35.4$ & $2.6-51.3$ & $2.6-51.3$ & \\
\hline
\end{tabular}




\section{DISCUSSION}

Thyroid cancer is the most frequent cancer among endocrine system malignancies (Rose et al., 2013) constituting approximately $1.0 \%$ of all new malignancies detected every year in USA. The incidence of thyroid cancer has trend towards overall increase in many countries with age adjusted incidence 5.1 per 100000 males and 14.9 per 100000 females in 2005 (Chen et al., 2009). We agree with Pellegriti that improved detection in preclinical stage is one of the possible reasons for this growing incidence (Pellegriti et al., 2013).

Worldwide, the most frequent histological type of thyroid cancer is papillary carcinoma. By SEER (Surveillance, Epidemiology and End Results) research database, papillary carcinoma represents $84 \%$ of thyroid cancer cases, followed by follicular carcinoma constituting $7.1 \%$ (varies from $7.1 \%$ to $10.4 \%$ in different regions) and medullary and anaplastic carcinoma comprising $0.97 \% \quad(0.72-1.61 \%)$ and $0.12 \%(0.4-0.23 \%)$, correspondingly. Female predominance is typical. The incidence varies by ethnic group with predominance to whites across all regions. Our data shows similar distribution of thyroid cancers: papillary carcinoma is the most frequent subtype $(78.9 \% ; 95 \% \mathrm{CI}=74.2-83.0)$ followed by follicular carcinoma $(16.6 \% ; 95 \% \mathrm{CI}=13.1-$ $21.2)$ and medullary and anaplastic carcinoma $(2.2 \%$; $95 \%$ CI $=1.1-4.4$ in both groups). In comparison with the SEER data, our group shows higher frequency of follicular, medullary and anaplastic carcinoma. Higher incidence of follicular carcinoma has been attributed to iodine deficiency (Mousavi et al., 2010; McHenry and Phitayakorn, 2011). Theoretically, higher frequency of non-papillary cancers can also be attributed to underdiagnostics of papillary carcinoma, especially papillary microcarcinoma. However, pTla papillary cancers in our group constitute a significant fraction - 50.2\% (95\% CI $=44.1-56.3)$ indicating careful examination. The difference between the frequency of pTla in papillary and follicular carcinoma reach statistical significance.

The mean age of patients at the time of cancer detection was 55.6 years $(95 \%$ CI $=53.9-57.3)$ for papillary carcinoma and 54.4 years $(95 \%$ CI $=49.9$ - 58.9) for follicular carcinoma. The mean age was slightly higher for medullary and anaplastic carcinoma but the differences did not reach statistical significance.

The majority of thyroid cancers were detected in pTl stage in patients aged $\geq 45$ years. However, in worldwide literature, higher aggressiveness is ascribed to thyroid cancer in older patients (American Thyroid Association Surgery Working Group et al., 2009; Ceresini et al., 2012). Hypothetically, the diagnosed pT1 papillary carcinomas in persons older than 45 years represent an aggressive still timely diagnosed subgroup. In accordance with this hypothesis, our data show relatively high frequency of pT3 papillary carcinoma, namely, $15.3 \%$ (95\% CI = $11.4-20.1)$ and pT3 follicular carcinomas reaching even $25.9 \%(95 \% \mathrm{CI}=16.1-38.9)$. Older age and advanced stage at the time of diagnosis are regarded significant adverse prognostic factors (Elisei et al., 2010) therefore the performed surgical treatment can theoretically decrease the mortality. More studies are necessary in this direction.

All histological subtypes of thyroid carcinoma are characterised by marked female predominance in accordance with the published findings (Boyle and Ferlay, 2005)

Evaluating the surgical treatment, total thyroidectomy was the most frequently used operation in case of papillary, follicular and especially medullary carcinoma. The rate of subtotal thyroidectomy and hemithyroidectomy was roughly equal in all groups. Radical surgical intervention was frequently impossible in anaplastic carcinoma. The frequency of total thyroidectomy in different regions of USA ranges 67.2 $75.5 \%$ that are only slightly higher values (Rose et al., 2013). Similarly, the proportion of total thyroidectomy in North-Eastern Italy is $67-78 \%$ over the time period $2000-2010$ (Pelizzo et al., 2013).

\section{CONCLUSIONS}

This is the first research work in Latvia that comprehends the overall review of morphological spectrum of thyroid carcinoma in the surgical material. Papillary and follicular carcinomas are the most frequently identified types in accordance with the global data. Much less common morphological forms of thyroid tumours were also diagnosed - medullary carcinoma and anaplastic thyroid carcinoma. The large mean diameter of follicular carcinoma in the surgery material and the fact that more than half of follicular carcinomas are revealed as pT2-T3 tumours highlights the necessity for up-to-dated diagnostics and elaboration of reliable novel molecular tests.

Acknowledgements: The research was carried out within the frames of scientific project RSU ZP 08/2013, supported by Rīga Stradiņš university

\section{Conflict of interest: None}

\section{REFERENCES}

1. Altman DG, Machin D, Bryant TN, Gardner RJ. Statistics with confidence. 2nd ed. Bristol: BMJ Books; 2000.

2. American Thyroid Association Surgery Working Group; American Association of Endocrine Surgeons; American Academy of OtolaryngologyHead and Neck Surgery; American Head and Neck Society, Carty SE, Cooper DS, Doherty GM, Duh QY, Kloos RT, Mandel SJ, Randolph GW, Stack BC Jr, Steward DL, Terris DJ, Thompson GB, Tufano RP, Tuttle RM, Udelsman R. Consensus statement on the terminology and classification of central neck dissection for thyroid cancer // Thyroid, 2009; 19(11):1153-1158

3. Boyle P, Ferlay J. Cancer incidence and mortality in Europe, 2004 // Ann Oncol., 2005; 16(3):481 - 488

4. Ceresini G, Corcione L, Michiara M, Sgargi P, Teresi G, Gilli A, Usberti E, Silini E, Ceda GP. Thyroid cancer incidence by histological typa and related variants in a mildly iodine-deficient area of 
northern Italy, 1998 to 2009 // Cancer, 2012; 118: $5473-5480$

5. Chen AY, Jemal A, Ward EM. Increasing incidence of differentiated thyroid cancer in the United States, 1988-2005 // Cancer, 2009; 1 15:3801 - 3807

6. Davies L, Welch HG. Increasing incidence of thyroid cancer in the United States, 1973 - 2002 // JAMA, 2006; 295(18):2164-2167

7. DeLellis RA, Lloyd RV, Heitz PU, Eng C. World Health Organization classification of tumours. Pathology and genetics of tumours of endocrine organs // IARC press, Lyon, France, 2004

8. Edge SB, Byrd DR, Compton CC, Fritz AG, Greene FL, Trotti A. AJCC cancer staging manual, 7th ed // Springer, New York, USA, 2010, pp.87-96

9. Elisei R, Molinaro E, Agate L, Bottici V, Masserini L, Ceccarelli C, Lippi F, Grasso L, Basolo F, Bevilacqua G, Miccoli P, Di Coscio G, Vitti P, Pacini F, Pinchera A. Are the clinical and pathological features of differentiated thyroid carcinoma really changed over the last 35 years? Study on 4187 patients from a single Italian institution to answer this question // J Clin Endocrinol Metab, 2010; 95(4):1516 - 1527

10. McHenry CR, Phitayakorn R. Follicular adenoma and carcinoma of the thyroid gland // Oncologist, $2011 ; 16(5): 585-593$
11. Mousavi SM, Brandt A, Sundquist J, Hemminki K. Risks of papillary and follicular thyroid cancer among immigrants to Sweden // Int J Cancer, 201 1; 129(9):2248 - 2255

12. Pelizzo M, Rubello D, Bernardi C, Gemo G, Bertazza L, Schievano E, Fedeli U. Thyroid surgical practices shaping thyroid cancer incidence in North-Eastern Italy // Biomed Pharmacother, 2013; doi: 10.1016/j. biopha.2013.10.001. [Epub ahead of print]

13. Pellegriti G, Frasca F, Regalbuto C, Squatrito S, Vigneri R. Worldwide increasing incidence of thyroid cancer: update on epidemiology and risk factors // J Cancer Epidemiol, 2013; doi: 10.1155/2013/965212.or 1 - 10

14. Rose J, Wertheim BC, Guerrero MA. Regional differences in thyroid cancer presentation and survival: A SEER study // Endocrine Practice, 2013; doi:10.4158/ep13046.or:1 - 32

\section{Address:}

Ilze Strumfa

Department of Pathology, Rīga Stradiņš university Dzirciema Street 16, LV-1007, Riga, Latvia

E-mail: Ilze.Strumfa@rsu.lv

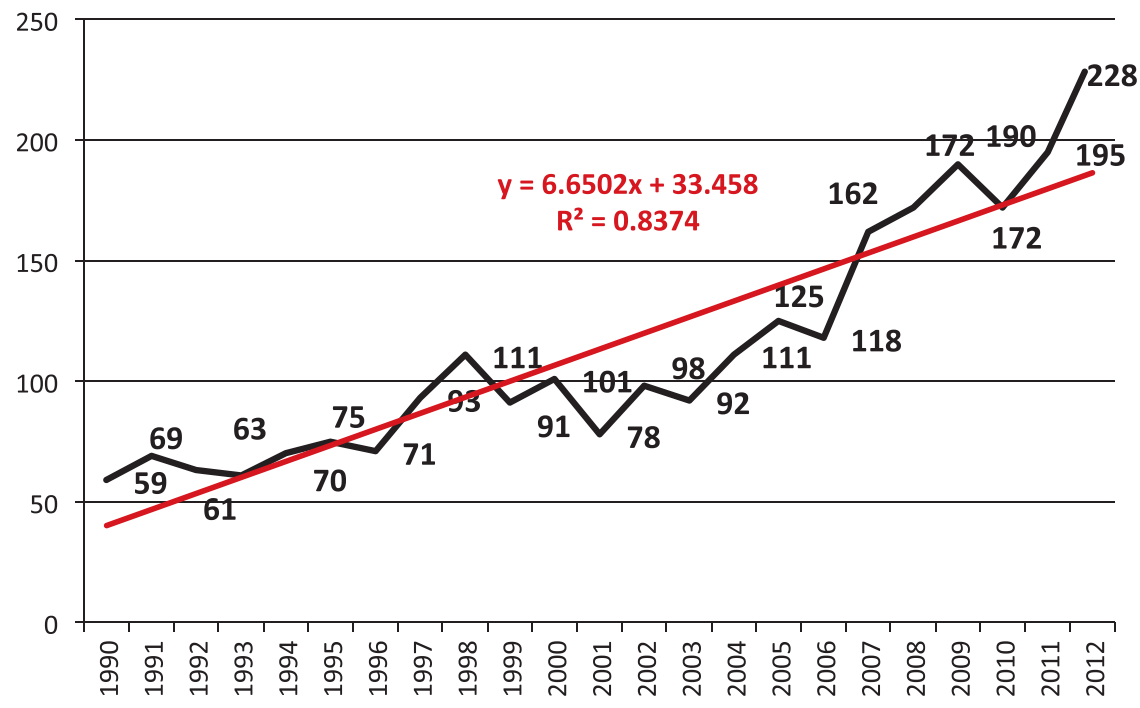

Fig. 1. The number of new thyroid cancer cases in Latvia per year, $1990-2012$. The vertical axis show the number of cases, the horizontal - year. Data - The Central Board of Statistics of the Republic of Latvia, accessed 11.11.2013. Analysis performed by the authors. 

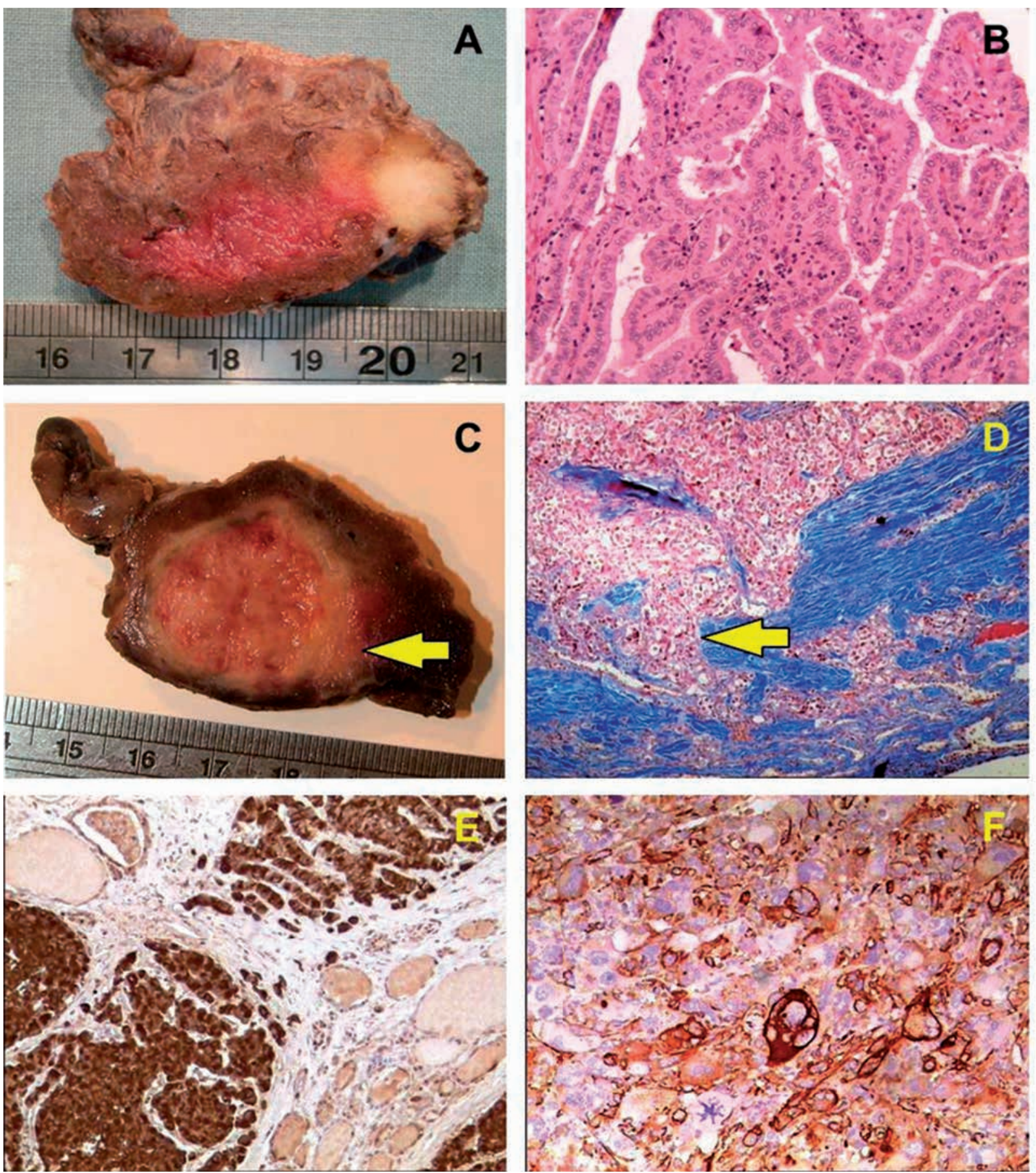

Fig. 2. The morphological spectrum of thyroid cancer. 1A, gross view of papillary carcinoma. 1B, Tissue structure of papillary carcinoma. Note the papillary architecture and typical nuclear structure. Haematoxylin-eosin, original magnification (OM) 200x. 1C. Gross view of follicular carcinoma. Note the outline deformity (at the arrow) suggesting invasive growth. 1D, Histologic findings confirming widespread cancer invasion (arrow) into full thickness of the fibrous capsule. Masson trichrome, OM 100x. 1E, Medullary thyroid carcinoma showing strong cytoplasmic expression of chromogranin A. Immunoperoxidase (IP), anti-chromogranin A, OM 50x. 1F, Anaplastic carcinoma. IP, anti-cytokeratin AE1/3, OM 100x. 